\title{
PENGEMBANGAN PERANGKAT PEMBELAJARAN MENGGAMBAR BERBASIS OUTDOOR LEARNING BAGI SISWA SEKOLAH DASAR
}

\author{
Atik Nur Wahyuningsih $^{1^{*}}$, Kustiarini ${ }^{2}$ \\ ${ }^{1}$ Sekolah Dasar Negeri 1 Tambak Boyolali \\ ${ }^{2}$ Pendidikan Guru Madrasah Ibtidaiyah FITK IAIN Surakarta \\ *Koresponden. E-mail: atiknurwahyuningsih89@gmail.com
}

\begin{abstract}
Abstrak
Tujuan penelitian ini ialah mendeskripsikan perangkat pembelajaran faktual yang ada dan karakteristik perangkat pembelajaran menggambar berbasis outdoor learning yang dikembangkan serta menguji kevalidan dan keefektifannya. Modifikasi penelitian $R$ and $D$ dengan model 3D Thiagarajan terdiri atas tahap pendefinisian, tahap perancangan, dan tahap pengembangan dengan subjek uji siswa kelas IV SDN 2 Singosari. Subjek tersebut dipilih dengan cara purposive sampling. Hasil penelitian ini memaparkan bahwa masih terdapat ketidaksesuaian isi dan antar komponen perangkat pembelajaran pada perangkat pembelajaran faktual yang digunakan oleh guru. Perangkat pembelajaran menggambar berbasis outdoor learning memiliki lima sintaks pembelajaran yaitu: (1) tahap pendahuluan, (2) tahap eksplorasi, (3) tahap outdoor learning berbasis lingkungan sekolah, (4) tahap elaborasi, dan (5) tahap presentasi. Rata-rata hasil validasi perangkat pembelajaran oleh ahli ialah 3,46 dalam kategori sangat valid. Hasil uji coba terhadap perangkat pembelajaran menunjukkan bahwa (1) pengukuran aspek kreativitas diperoleh rata-rata 7,01, (2) aktivitas siswa diperoleh persentase $66,87 \%$ dalam kategori aktif, (3) persentase respons siswa terhadap pelaksanaan perangkat pembelajaran sebesar $83,05 \%$ dalam kategori sangat positif, dan (4) persentase respons guru pada perangkat pembelajaran sebesar $85 \%$ dalam kategori sangat positif. Produk akhir penelitian berupa buku pedoman guru perangkat pembelajaran menggambar berbasis outdoor learning.
\end{abstract}

Kata Kunci: Kreativitas, Outdoor Learning, Perangkat Pembelajaran

\section{THE DEVELOPMENT OF DRAWING LEARNING INSTRUMENTS BASED OUTDOOR LEARNING FOR ELEMENTARY STUDENTS}

\begin{abstract}
This research purpose to describe factually learning instrument dan characteristics of learning instrument was developed and acquiring products of drawing learning instrument that are valid and effective. The $R$ and $D$ research design used modifications Thiagarajan $3 D$ model consisting of definition phase, design phase and development phase with research subjects are students of fourth grade at Singosari 2 Elementary School were selected by purposive sampling. The results showed are learning instruments in fact still found mismatch content and components. Drawing learning instruments based on outdoor learning that has five syntax, such as: (1) preliminary, (2) exploration, (3) outdoor learning based school environment, (4) elaboration, and (5) presentation. The validation result of learning instruments obtained an average of 3.46, it is include of very valid category. The result of learning instrument trials shows that: (1) measurement creativity is 7.01 an average, (2) percentage student's activity get $66.87 \%$ in active category, (3) percentage student's response of learning implementation get $83,05 \%$ in very positive category, and (4) percentage teacher's respons of lesson plan get $85 \%$ in very positive category. The final product of the research was in the form of a teacher manual on drawing learning devices based on outdoor learning.
\end{abstract}

Keywords: Creativity, Outdoor Learning, Learning Instruments

Copyright $\odot 2018$, JRPD, ISSN 2615 - 1723 (Print), ISSN 2615 - 1766 (Online) 


\section{Jurnal Riset Pendidikan Dasar, 01 (2), Oktober 2018 (84-100)}

Atik Nur Wahyuningsih, Kustiarini

\section{PENDAHULUAN}

Perangkat pembelajaran merupakan sekumpulan media atau sarana dalam proses pembelajaran yang digunakan oleh guru untuk membatu pencapaian hasil belajar yang sudah ditetapkan. Perangkat pembelajaran dapat berupa silabus, rencana pelaksanaan pembelajaran, lembar kegiatan siswa, instrumen penilaian atau tes hasil belajar, media pembelajaran dan buku ajar. Perangkat pembelajaran disiapkan sebelum melaksanakan pembelajaran agar kegiatan terarah dan berjalan dengan baik dalam upaya mencapai tujuan pembelajaran. Berdasarkan Peraturan Menteri Pendidikan dan Kebudayaan (2016:6), setiap pendidik berkewajiban menyusun perangkat pembelajaran secara lengkap dan sistematis

Proses pembelajaran pada satuan pendidikan diselenggarakan secara interaktif, inspiratif, menyenangkan, menantang, memotivasi siswa untuk berpartisipasi aktif, serta memberikan ruang yang cukup bagi prakarsa, kreativitas dan kemandirian sesuai bakat, minat, perkembangan fisik dan psikologis siswa, (Peraturan Menteri Pendidikan dan Kebudayaan Nomor 22 tahun 2016 tentang Standar Proses). Namun, aspek kreativitas belum mendapatkan pembinaan yang cukup, bahkan terkadang terabaikan dalam berbagai mata pelajaran (Tabrani, 2014:6).

Kreativitas sangat diperlukan bagi siswa agar mampu mengikuti perubahan-perubahan yang terjadi dan menghadapi permasalahanpermasalahan yang semakin kompleks pada perkembangan IPTEK saat ini. Sebagai pribadi atau kelompok, seseorang harus mampu berfikir, membentuk cara-cara baru secara kreatif agar dapat bertahan dan tidak tertinggal dalam persaingan antarbangsa dan negara. mengembangkan kreativitas anak sejak usia dini sangat penting karena (1) dapat mewujudkan (mengaktualisasikan) diri yang merupakan tingkatan tertinggi dari kebutuhan pokok dalam hidup manusia (Hukum Maslow), (2) kreativitas sebagai suatu kemampuan untuk menganalisis kemungkinan-kemungkinan penyelesaian terhadap suatu masalah masih kurang mendapat perhatian dalam pendidikan, (3) kreativitas dapat memberikan kepuasan serta bermanfaat bagi diri sendiri dan lingkungan, dan (4) kreativitas berupa ide, penemuan, dan teknologi yangg bersifat baru, diperlukan untuk kesejahteraan pada era pembangunan (Munandar, 2012:31-32). Kreativitas paling mudah dikembangkan melalui kegiatan seni karena pada hakikatnya seni lebih dekat dengan kreativitas. Dari jenis-jenis seni yang ada, menggambar merupakan kegiatan yang digemari anak-anak, terlepas dari anak memiliki bakat menggambar atau tidak (Tabrani, 2014:6).

Hasil observasi dan wawancara kepada guru kelas IV SDN 2 Singosari menunjukkan bahwa proses pembelajaran menggambar masih berpusat pada guru. Guru menggunakan strategi ceramah yaitu guru menjelaskan materi pembelajaran yang disediakan oleh pemerintah kepada siswa dan metode demonstrasi dengan memperagakan contoh gambar di papan tulis. Guru belum menguasai teknik-teknik menggambar. Hasil menggambar siswa belum maksimal ditunjukkan dengan hasil gambar yang kurang bervariasi dan stereotip (pengulangan) yaitu siswa menggambar dengan objek yang sama dan diulang-ulang.

Belajar pada hakikatnya merupakan interaksi yang terjadi antara individu dengan lingkungan. Pernyataan tersebut sesuai dengan teori Discovey Learning yang disampaikan oleh Bruner (1977:89) bahwa lingkungan berpengaruh terhadap tingkah laku manusia. Jika dalam pembelajaran guru bersedia memberikan kesempatan pada siswa untuk menemukan konsep, teori aturan, atau pemahaman langsung melalui contoh-contoh yang dijumpai di lingkungan, maka pembelajaran akan berjalan secara baik dan kreatif. Rousseau dengan teori "Kembali ke Alam" menjelaskan bahwa 
pendidikan anak harus dilakukan di lingkungan alam sehingga anak dapat tumbuh menjadi manusia yang baik (dalam Hamalik, 2004:194). Ligthart dengan teori "Pengajaran Alam Sekitar" berpendapat bahwa pendidikan sebaiknya disesuaikan dengan keadaan alam sekitar yang merupakan segala sesuatu yang ada di sekitar kita (dalam Hamalik, 2004:195). Dari pendapat tohoh-tokoh tersebut, maka dapat disimpulkan bahwa lingkungan merupakan bagian dasar pendidikan atau pengajaran yang penting sebagai dasar pengembangan suatu model pembelajaran yang berorientasi pada lingkungan.

Salah satu strategi pembelajaran yang relevan dengan pendapat Bruner, Rousseau dan Ligthart yang digunakan untuk memperbaiki kualitas pembelajaran menggambar dan untuk mencapai tujuan pembelajaran pengembangan kreativitas adalah outdoor learning. Outdoor learning adalah pembelajaran yang memanfaatkan lingkungan menjadi sarana pembelajaran. Lingkungan memiliki sumber dan kaya akan media pembelajaran. Sumber belajar dari lingkungan semakin menambah pengetahuan dan wawasan karena siswa belajar langsung dari sumbernya. Selain itu, kegiatan pembelajaran dimungkinkan lebih menarik untuk siswa karena banyaknya macam-macam media/benda yang ada di lingkungan. Husamah (2013:21\&24) mengungkapkan bahwa pembelajaran di luar ruangan (Outdoor Learning) mampu memunculkan proses komunikasi, pemecahan masalah, kreativitas, pengambilan keputusan, saling memahami, menghargai perbedaan, serta cenderung fleksibel proses pembelajarannya, lebih mengutamakan kreativitas dan inisiatif berdasarkan daya nalar siswa.

Berpijak pada uraian di atas, maka dikembangkan perangkat pembelajaran menggambar dengan strategi pembelajaran outdoor learning. Pengembangan perangkat pembelajaran berbasis outdoor learning diharapkan dapat memperbaiki kualitas pelaksanaan pembelajaran menggambar dan mengembangkan kreativitas siswa. Pengembangan perangkat pembelajaran menggambar terintegrasi dengan mapel lain yang dihubungkan dalam sebuah tema dan sub tema (tematik terpadu) yang merupakan karakteristik pembelajaran pada kurikulum 2013.

\section{METODE}

Penelitian ini adalah penelitian dan pengembangan (Research and Development) yang dimodifikasi dari model pengembangan Thiagarajan, Semmel dan Semmel. Produk yang dikembangkan berupa perangkat pembelajaran menggambar berbasis outdoor learning meliputi RPP, materi pembelajaran, pengukuran kreativitas siswa dan buku pedoman guru.

Penelitian ini menggunakan model pengembangan perangkat pembelajaran modifikasi model 3-D Thiagarajan yang meliputi define, design, develop. Model 3-D Thiagarajan dipilih karena tahap-tahap pelaksanaannya lebih detail, sistematis dan melibatkan penilaian ahli sehingga perangkat pembelajaran telah direvisi berdasarkan penilaian dan saran ahli sebelum dilaksanakan uji coba lapangan.

Modifikasi model pengembangan 3D Thiagarajan, Semmel and Semmel terdapat pada Gambar 1.

Pelaksanaan uji coba lapangan berkolaborasi dengan guru kelas IV SDN 2 Singosari sebagai guru model. Guru model berfungsi sebagai pelaksana perangkat pembelajaran menggambar berbasis outdoor learning di kelas dan di luar kelas. Guru model diharapkan dapat memberikan respons terhadap perangkat pembelajaran menggambar berbasis outdoor learning yang telah dikembangkan.

$$
\text { Copyright } \text { C2018, JRPD, ISSN } 2615 \text { - } 1723 \text { (Print), ISSN } 2615 \text { - } 1766 \text { (Online) }
$$


Jurnal Riset Pendidikan Dasar, 01 (2), Oktober 2018 (84-100)

Atik Nur Wahyuningsih, Kustiarini

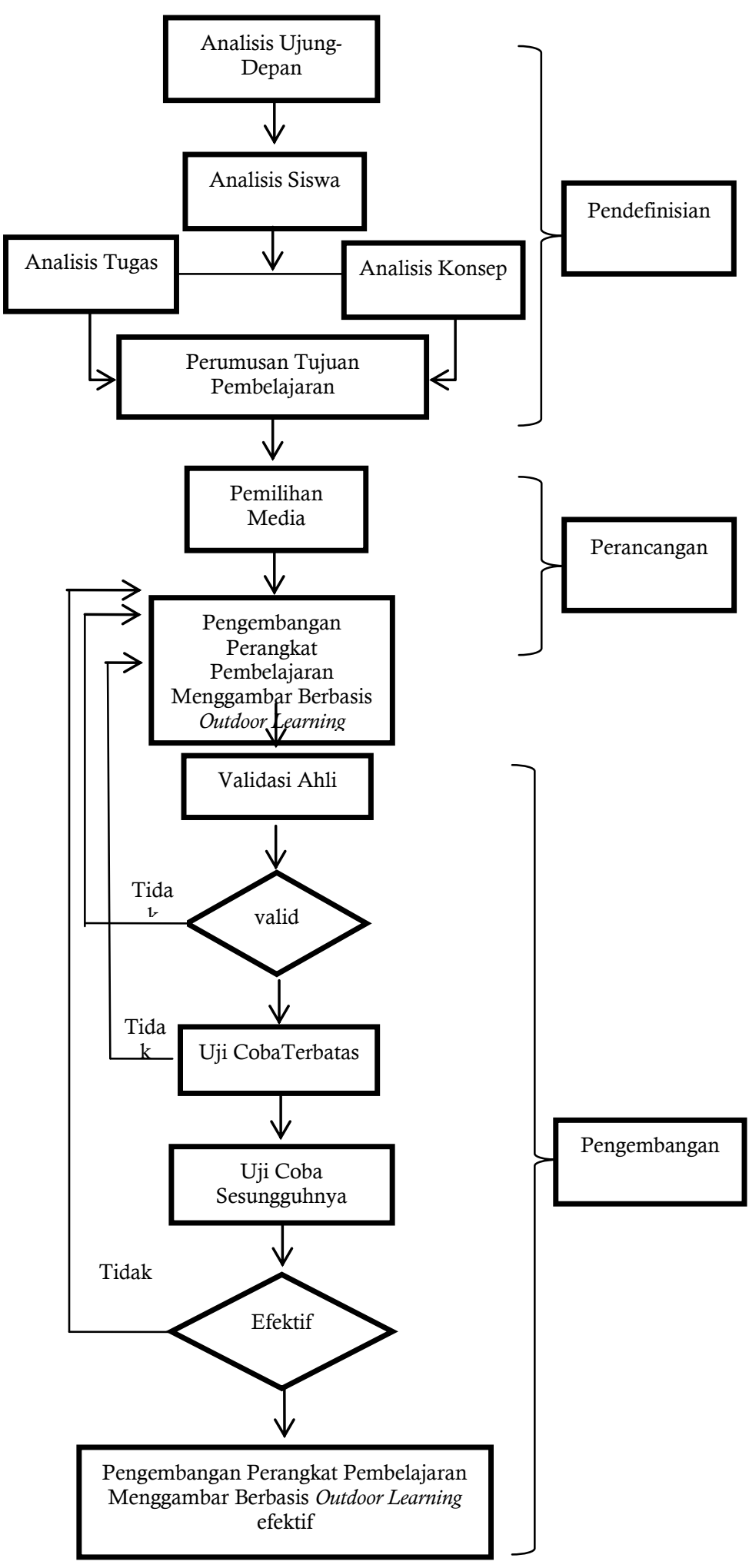

Gambar 1. Modifikasi Model Pengembangan 3D Thiagarajan, Semmel and Semmel
Uji coba produk dilaksanakan menggunakan pretest-posttest control group design. Desain ini digunakan untuk menguji perangkat pembelajaran menggambar. Pada pelaksanaan uji coba terdapat dua kelompok yaitu kelompok ekperimen dan kelompok kontrol. Bentuk desainnya sebagai berikut (Sugiyono, 2013:416).

\begin{tabular}{|cccc|}
\hline $\mathrm{R}$ & $O_{1}$ & & $O_{2}$ \\
& & $\mathrm{X}$ & \\
$\mathrm{R}$ & $O_{3}$ & & $O_{4}$ \\
\hline
\end{tabular}

Gambar 2. Desain Eksperimen dengan Model Pretest - Posttest Control Group Sumber :

\section{Keterangan :}

$$
\begin{aligned}
O_{1}= & \text { Kreativitas awal kelompok eksperimen } \\
O_{2}= & \text { Kreativitas akhir kelompok eksperimen } \\
O_{3}= & \text { Kreativitas awal kelompok kontrol } \\
O 4= & \text { Kreativitas akhir kelompok kontrol } \\
X= & \text { Pembelajaran menggambar berbasis } \\
& \text { Outdoor Learning }
\end{aligned}
$$

Subjek penelitian adalah siswa kelas IV SDN 1 Tambak dan SDN 2 Singosari Boyolali tahun ajaran 2015/2016. Subjek uji siswa kelas IV SDN 1 Tambak sebagai kelas kontrol sebanyak 19 siswa dan siswa kelas IV SDN 2 Singosari sebagai kelas eksperimen sebanyak 21 siswa. Subjek penelitian dipilih menggunakan teknik purposive sampling yaitu pengambilan sampel dengan mempertimbangkan hal-hal tertentu. Dasar pertimbangan pemilihan subjek penelitian adalah kondisi lingkungan sekolah yang memiliki berbagai jenis tumbuhan dan dikelilingi oleh ladang, menyesuaikan dengan tema serta sub tema pada pembelajaran menggambar kelas IV di Semester 1. 


\section{Jurnal Riset Pendidikan Dasar, 01 (2), Oktober 2018 (84-100)}

Atik Nur Wahyuningsih, Kustiarini

Sumber data adalah subjek dari mana suatu data diperoleh (Arikunto, 2010:144). Sumber data yang digunakan adalah hasil observasi awal penelitian, hasil wawancara guru kelas IV, hasil validasi perangkat pembelajaran oleh para ahli, hasil pengukuran kreativitas menggambar siswa, data aktivitas siswa dalam proses pembelajaran, hasil respons guru pada perangkat pembelajaran dan respons siswa terhadap pelaksanaan pembelajaran, daftar nama-nama siswa kelas IV SDN 2 Singosari dan daftar nama siswa kelas IV SDN 1 Tambak, serta Rencana Pelaksanaan Pembelajaran menggambar factual.

Teknik analisis data yang digunakan antara lain:

\section{Analisis Validitas Perangkat Pembelajaran}

Validasi ahli terhadap perangkat pembelajaran menggambar yang meliputi RPP, materi pembelajaran dan pengukuran kreativitas menggunakan validitas isi. Kriteria penilaian validitas perangkat pembelajaran menggunakan skala 4 yaitu 4 (sangat valid), 3 (valid), 2 (cukup valid) dan 1 (tidak valid). Hasil validasi ahli dihitung menggunakan rata-rata skor validasi perangkat. Data berupa skor dan uraian saran. Uraian saran dirangkum dan dideskripsikan secara naratif untuk dasar revisi perangkat nemhelaiaran

$$
\text { Rata-rata skor validasi }=\frac{\text { jumla } h \text { skor seluru } h \text { item }}{\text { banyak } \text { item }}
$$

Tabel 1. Kriteria Validasi Perangkat Pembelajaran

\begin{tabular}{cc}
\hline Skor & Nilai \\
\hline $1,00 \leq S \leq 1,75$ & Tidak valid \\
\hline $1,76 \leq S \leq 2,50$ & Kurang valid \\
\hline $2,51 \leq \mathrm{S} \leq 3,25$ & Valid \\
\hline $3,26 \leq \mathrm{S} \leq 4,00$ & Sangat valid \\
\hline
\end{tabular}

\section{Analisis Kreativitas Siswa}

Aspek kreativitas meliputi kelancaran, keaslian, keluwesan dan kerincian. Aspek kelancaran terdiri dari tiga indikator. Aspek keaslian terdiri dari dua indikator. Aspek keluwesan terdiri dari dua indikator. Aspek kerincian terdiri dari tiga indikator. Setiap indikator yang terpenuhi diberi skor 1 sedangkan indikator yang tidak terpenuhi diberi skor 0 dan skor maksimal adalah 10. Kreativitas siswa diukur menggunakan Sign Tes dengan taraf kesalahan terbesar $5 \%$.

Rumus: $p\left(X_{A}>X_{B}\right)=p\left(X_{A}<X_{B}\right)=0,5$

$$
\text { Sumber : Sugiyono (2012) }
$$

\section{Analisis Observasi Aktivitas Siswa}

Data aktivitas siswa selama proses pembelajaran menggambar didasarkan pada pengamatan yang dianalisis secara deskriptif kualitatif. Aktivitas siswa terdiri dari delapan aspek (Sadiman 2011:101). Setiap aspek terdiri dari 4 indikator, setiap indikator memiliki skor 1 . Data aktivitas siswa dihitung dengan menjumlahkan skor tiap aspek aktivitas siswa.

Tabel 2. Kategori Aktivitas Siswa

\begin{tabular}{cl}
\hline Skor & \multicolumn{1}{c}{ Kategori } \\
\hline$\geq 27$ & Sangat aktif \\
\hline $20-26$ & Aktif \\
\hline $13-19$ & Tidak aktif \\
\hline$\leq 12$ & Sangat tidak aktif
\end{tabular}

Sumber : Mardapi (2012)

4. Analisis Angket Respons Siswa dan Guru Data respons siswa dan guru dihitung dengan cara menjumlahkan skor yang diperoleh pada setiap pernyataan pada angket respons.

Tabel 3. Kategori Respons Siswa

\begin{tabular}{cl}
\hline Skor & \multicolumn{1}{c}{ Kategori } \\
\hline $30-36$ & Sangat positif \\
\hline $23-29$ & Positif \\
\hline $16-22$ & Negatif \\
\hline $0-15$ & Sangat negatif \\
\hline
\end{tabular}

Copyright $\odot 2018$, JRPD, ISSN 2615 - 1723 (Print), ISSN 2615 - 1766 (Online) 
Jurnal Riset Pendidikan Dasar, 01 (2), Oktober 2018 (84-100)

Atik Nur Wahyuningsih, Kustiarini

Tabel 4. Kategori Respons Guru

\begin{tabular}{cl}
\hline Skor & \multicolumn{1}{c}{ Kategori } \\
\hline $33-40$ & Sangat positif \\
\hline $25-32$ & Positif \\
\hline $17-24$ & Negatif \\
\hline $0-16$ & Sangat negatif \\
\hline \multicolumn{2}{c}{ Sumber : Mardapi (2012) }
\end{tabular}

5. Analisis Data Dokumentasi

Analisis data dokumentasi yang berupa RPP menggambar faktual adalah dengan menelaah isi setiap komponen RPP dan kesesuaian isi antarkomponen RPP. Penelaahan isi RPP didasarkan pada karakteristik pembelajaran, Standar Isi dan Standar Proses pada kurikulum 2013. Hasil analisis RPP faktual dijadikan dasar pengembangan perangkat pembelajaran menggambar berbasis outdoor learning.

\section{HASIL DAN PEMBAHASAN}

\section{HASIL}

Perangkat pembelajaran menggambar berbasis outdoor learning divalidasi oleh validator ahli tematik dan praktisi pendidikan. Hasil rekapitulasi skor validasi ahli terhadap perangkat pembelajaran berbasis outdoor learning yaitu RPP 1 diperoleh rata-rata 3,69 dalam kategori sangat baik, RPP 2 diperoleh rata-rata 3,63 dalam kategori sangat baik dan RPP 3 diperoleh ratarata 3,63 dalam kategori sangat baik. Tabel 5 menunjukkan validitas perangkat pembelajaransebesar 3,65 dalam kategori sangat baik.

Tabel 5. Rekapitulasi Validasi Perangkat Pembelajaran Menggambar

\begin{tabular}{|c|c|c|c|c|c|c|}
\hline \multirow{2}{*}{ No. } & \multirow{2}{*}{ PP } & \multicolumn{3}{|c|}{ Validator } & \multirow{2}{*}{$\mathrm{R}$} & \multirow{2}{*}{ Kat } \\
\hline & & 1 & 2 & 3 & & \\
\hline 1. & RPP 1 & 4 & 3,27 & 3,81 & 3,69 & SB \\
\hline 2. & RPP 2 & 3,81 & 3,18 & 3,90 & 3,63 & SB \\
\hline 3. & RPP 3 & 3,81 & 3,27 & 3,81 & 3,63 & SB \\
\hline & $\mathbf{R}$ & 3,87 & 3,24 & 3,84 & 3,65 & SB \\
\hline
\end{tabular}

Copyright $\odot 2018$, JRPD, ISSN 2615 - 1723 (Print), ISSN 2615 - 1766 (Online)
Keterangan:

$\begin{array}{ll}P P & : \text { Perangkat pembelajaran } \\ R & : \text { Rata-rata } \\ \text { Kat } & : \text { Kategori }\end{array}$

Aspek perangkat pembelajaran yang divalidasi berjumlah 11 aspek yang terdiri atas: (1) identitas mata pelajaran, (2) kompetensi inti, (3) komptensi dasar, (4) indikator, (5) tujuan pembelajaran, (6) materi pembelajaran, (7) metode dan pendekatan pembelajaran, (8) media, alat dan sumber belajar, (9) langkah-langkah pembelajaran, (10) penilaian autentik, dan (11) tata bahasa. Aspek identitas mata pelajaran, kompetensi inti (KI) mendapat skor tertinggi yaitu 4. Aspek kompetensi dasar (KD) berada di urutan kedua dengan skor 3,89. Aspek tujuan pembelajaran, metode dan pendekatan pembelajaran, media, alat dan sumber belajar, serta langkah-langkah pembelajaran berada di urutan ketiga dengan skor 3,66. Aspek materi pembelajaran dan penilaian autentik di urutan keempat dengan skor 3,44 dan aspek indikator dan tata bahasa berada di urutan kelima dengan skor 3,22. Rata-rata dari semua aspek adalah 3,62 dalam kategori sangat baik. Rincian skor perangkat pembelajaran validasi ahli dapat dilihat pada Tabel 6 .

Tabel 6. Rekapitulasi Setiap Aspek Perangkat Pembelajaran

\begin{tabular}{|c|c|c|c|c|c|}
\hline \multirow{2}{*}{ Aspek } & \multicolumn{3}{|c|}{ RPP } & \multirow{2}{*}{$\mathrm{R}$} & \multirow{2}{*}{ Ket } \\
\hline & 1 & 2 & 3 & & \\
\hline A & 4 & 4 & 4 & 4 & SB \\
\hline$B$ & 4 & 4 & 4 & 4 & SB \\
\hline C & 4 & 3,67 & 4 & 3,89 & SB \\
\hline $\mathrm{D}$ & 3,67 & 3 & 4 & 3,22 & SB \\
\hline $\mathrm{E}$ & 4 & 3 & 4 & 3,66 & SB \\
\hline $\mathrm{F}$ & 4 & 3 & 3,33 & 3,44 & SB \\
\hline G & 4 & 3 & 4 & 3,66 & SB \\
\hline $\mathrm{H}$ & 4 & 3 & 4 & 3,66 & SB \\
\hline I & 4 & 3 & 4 & 3,66 & SB \\
\hline $\mathrm{J}$ & 3,33 & 3 & 4 & 3,44 & SB \\
\hline $\mathrm{K}$ & 3,67 & 3 & 3 & 3,22 & SB \\
\hline $\mathbf{R}$ & 3,87 & 3,24 & 3,27 & 3,62 & SB \\
\hline
\end{tabular}




\section{Keterangan:}

$\begin{array}{cl}P P & : \text { Perangkat pembelajaran } \\ R & : \text { Rata-rata } \\ \text { Kat } & : \text { Kategori } \\ S B & : \text { Sangat Baik } \\ A & : \text { identitas mata pelajaran } \\ B & : \text { kompetensi inti } \\ C & : \text { komptensi dasar } \\ D & : \text { indicator } \\ E & : \text { tujuan pembelajaran } \\ F & : \text { materi pembelajaran } \\ G & : \text { metode dan pendekatan pembelajaran } \\ H & : \text { media, alat dan sumber pembelajaran } \\ I & : \text { langkah-langkah pembelajaran } \\ J & : \text { penilaian autentik } \\ K & : \text { tata bahasa }\end{array}$

Efektifitas perangkat pembelajaran menggambar berbasis outdoor learning hasil uji coba sesungguhnya dilihat dari empat aspek yaitu aktivitas siswa, respons siswa, respons guru dan kreativitas siswa. Hasilnya ialah dari 21 siswa terdapat 2 siswa $(9,5 \%)$ dalam kategori sangat aktif, terdapat 16 siswa $(76,2 \%)$ termasuk dalam kategori aktif dan terdapat 3 siswa $(14,3 \%)$ siswa dalam kategori kurang aktif. Melalui pembelajaran menggambar berbasis outdoor learning dapat meningkatkan aktivitas siswa meliputi kegiatan melihat, kegiatan mendengarkan, kegiatan gerak, kegiatan mental dan kegiatan emosional. Kegiatan lisan, kegiatan menulis, dan kegiatan menggambar perlu ditingkatkan lagi.

Respons siswa terhadap pembelajaran diperoleh rata-rata sebesar 29,90 (83,05\%) dalam kategori sangat positif. Respons tertinggi oleh siswa berkaitan dengan proses pembelajaran yang tidak membosankan diperoleh rata-rata 3,72. Respons siswa senang terhadap materi pembelajaran diperoleh rata-rata 3,68. Respons dalam mengikuti proses pembelajaran diperoleh rata-rata 3,59. Respons dalam menemukan ide/gagasan dalam menggambar diperoleh ratarata 3,54. Respons tentang suasana pembelajaran yang menyenangkan diperoleh rata-rata 3,45. Respons tentang pembelajaran outdoor learning yang menyenangkan diperoleh rata-rata 3,31. Respons tentang senang belajar di lingkungan terbuka diperoleh rata-rata 3,27. Respons tentang senang terhadap pendekatan outdoor learning yang digunakan pada pembelajaran diperoleh rata-rata 3,09. Respons tentang cara mengajar guru diperoleh rata-rata 2,9.

Respons guru terhadap perangkat pembelajaran menggambar berbasis outdoor learning terdiri atas 9 pernyataan. Perangkat pembelajaran menggambar berbasis outdoor learning mudah diterapkan oleh guru, guru dimudahkan dalam melaksanakan proses pembelajaran, kreativitas siswa dapat dikembangkan melalui pembelajaran menggambar dan format penulisan perangkat pembelajaran menggambar diperoleh skor 4 . Bahasa dan kalimat dalam perangkat pembelajaran, perangkat pembelajaran menggambar berbasis outdoor learning dapat meningkatkan aktivitas siswa, penilaian pada perangkat pembelajaran mudah diterapkan, cakupan dan kedalaman materi pembelajaran cukup memadai, perangkat pembelajaran menggambar dapat mengatasi kesulitan ide/gagasan siswa dalam menggambar serta siswa senang, semangat dan antusias mengikuti pembelajaran diperoleh skor 3. Secara keseluruhan diperoleh skor 34 dengan persentase $85 \%$ dalam kategori sangat positif.

Uji homogenitas data pretest kelas eksperimen dan kontrol menggunakan Uji Levene melalui SPSS 17 dengan taraf signifikansi sebesar \%5. Data homogen jika nilai signifikansi hitung lebih besar dari pada 5\%. Hasil uji menunjukkan nilai signifikansi data pretest sebesar 0,833 dengan hasil $0,833>0,05$, maka dapat disimpulkan bahwa sampel memiliki varians yang sama atau homogen.

Uji homogenitas data posttest kelas eksperimen dan kontrol menggunakan Uji Levene melalui SPSS 17 dengan taraf siginifikansi 


\section{Jurnal Riset Pendidikan Dasar, 01 (2), Oktober 2018 (84-100)}

Atik Nur Wahyuningsih, Kustiarini

sebesar \%5. Data homogen jika nilai signifikansi hitung lebih besar dari pada 5\%. Hasil uji menunjukkan nilai signifikansi data posttest sebesar 0,746 dengan hasil 0,746 >0,05, maka dapat disimpulkan bahwa sampel memiliki varians yang sama atau homogen. Data yang diperoleh dari kelas kontrol dan eksperimen menunjukkan homogenitas dan tidak berdistribusi normal karena sampel di bawah 30, maka kreativitas siswa dihitung menggunakan uji statistik non parametris.

Rata-rata kreativitas siswa dapat dilihat pada Tabel 7.

Tabel 7. Hasil Kreativitas Menggambar Siswa

\begin{tabular}{ccccc}
\hline \multirow{2}{*}{$\begin{array}{c}\text { Sumber } \\
\text { variasi }\end{array}$} & \multicolumn{2}{c}{ Kontrol } & \multicolumn{2}{c}{ Eksperimen } \\
\cline { 2 - 5 } & Pre test & $\begin{array}{c}\text { Post } \\
\text { test }\end{array}$ & Pre test & Post test \\
\hline $\begin{array}{c}\text { Skor } \\
\text { maksimal }\end{array}$ & 8 & 7,3 & 7 & 7,67 \\
\hline $\begin{array}{c}\text { Skor } \\
\text { minimal }\end{array}$ & 2 & 4,3 & 3 & 5,67 \\
\hline Rata-rata & $\mathbf{5 , 0 5}$ & $\mathbf{5 . 9 2}$ & $\mathbf{4 . 5 7}$ & $\mathbf{7 . 0 1}$ \\
\hline
\end{tabular}

Hasil Uji Sign pada kelas kontrol dengan jumlah 19 siswa, diperoleh hasil siswa yang mengalami penurunan sebanyak 4 siswa $(21,05 \%)$, siswa yang tidak mengalami perubahan sebanyak 0 siswa $(0 \%)$, siswa yang mengalami peningkatan sebanyak 15 siswa (78,95\%), dengan exact sig. (2-tailed) sebesar 0,019 . Taraf signifikasi sebesar $5 \%(0,05)$, maka harga 0,019 lebih kecil dari 0,05. Maka disimpulkan bahwa terdapat pengaruh yang positif dan signifikan pembelajaran menggunakan media gambar dan video terhadap pengembangan kreativitas siswa.

Pada kelas eksperimen yang berjumlah 21 siswa, diperoleh hasil siswa yang mengalami penurunan sebanyak 1 siswa $(4,76 \%)$, siswa yang tidak mengalami perubahan sebanyak 1 siswa $(4,77 \%)$, siswa yang mengalami peningkatan sebanyak 19 siswa $(90,47 \%)$, dan. Kolom exact sig, (2-tailed) diperoleh angka sebesar 0,00 dengan taraf signifikansi sebesar 0,05 sehingga harga
0,00 lebih kecil dari 0,05. Maka disimpulkan bahwa pembelajaran outdoor learning memberikan pengaruh yang positif dan signifikan pada pembelajaran.

Tabel 8. Perbandingan Hasil Uji Sign Kelas Eskperimen dan Kontrol

\begin{tabular}{lccc}
\hline \multicolumn{1}{c}{ Variasi } & & Kontrol & Eksperimen \\
\hline $\begin{array}{l}\text { sesudah } \\
\text { sebelum }\end{array}$ & $<$ & $21,05 \%$ & $4,76 \%$ \\
\hline $\begin{array}{l}\text { sesudah } \\
\text { sebelum }\end{array}$ & $>$ & $78,95 \%$ & $90,47 \%$ \\
\hline $\begin{array}{l}\text { sesudah } \\
\text { sebelum }\end{array}$ & $=$ & $0 \%$ & $4,77 \%$ \\
\hline $\begin{array}{l}\text { Taraf } \\
\text { signifikansi }\end{array}$ & & 0,05 & 0,05 \\
\hline $\begin{array}{l}\text { Exact sig. } \\
\text { tailed) }\end{array}$ & (2- & 0,019 & 0,000 \\
\hline Hasil & Berpengaruh & Berpengaruh \\
\hline
\end{tabular}

\section{Hasil Pengembangan}

Model pengembangan yang digunakan pada penelitian ini adalah modifikasi model 3D Thiagarajan. Tahapan-tahapan dalam pengembangan perangkat pembelajaran yaitu: (1) tahap pendefinisian, (2) tahap perancangan dan (3) tahap pengembangan. Tahap-tahap pengembangan perangkat pembelajaran disajikan sebagai berikut:

\section{Tahap Pendefinisian}

Tahap pendefinisian bertujuan untuk menetapkan dan mendefinisikan kebutuhan pembelajaran. Tahap pendefinisian diperlukan untuk menentukan perencanaan yang tepat dan objektif dalam menyusun perangkat pembelajaran berbasis outdoor learning untuk mengembangkan kreativitas siswa. Tahap pendefisian meliputi:

a. Analisis Ujung Depan

Observasi pembelajaran khususnya menggambar di SDN 2 Singosari, kabupaten Boyolali diperoleh hasil bahwa metode/teknik pembelajaran yang digunakan oleh guru kurang bervariasi. Guru belum memanfaatkan media Copyright $@ 2018$, JRPD, ISSN 2615 - 1723 (Print), ISSN 2615 - 1766 (Online) 
pembelajaran menggambar. Hasil menggambar siswa cenderung stereotip dan kurang variasi. Berdasarkan hasil wawancara dengan guru, selama ini pembelajaran dilaksanakan di dalam kelas, belum memanfaatkan lingkungan sekitar sekolah sebagai sumber dan media pembelajaran. Berdasarkan analisis tersebut maka dipilih alternatif pengembangan perangkat pembelajaran berbasis outdoor learning dengan memanfaatkan lingkungan sekitar sekolah seperti tanaman, ladang atau kebun dan kegiatan menyiram tanaman dan bunga sebagai sumber dan media belajar. Siswa diharapkan dapat menggambar sesuai tema dan sub tema yang telah ditentukan sesuai karakteristik dan kemampuan siswa masing-masing secara kreatif. Permasalahan dan solusi sudah ditemukan, langkah-langkah pengembangan dapat dilanjutkan dengan tahap analisis siswa.

b. Analisis Siswa

Analisis siswa bertujuan untuk mengembangkan perangkat pembelajaran sesuai karakteristik siswa. Berdasarkan observasi pelaksanaan pembelajaran di SDN 1 Tambak, siswa merasa senang dan antusias dalam menggambar namun gambar yang dibuat masih stereotip (mengulang) dan kurang variasi. Kreativitas siswa khususnya pada pembelajaran menggambar belum diperhatikan. Berdasarkan analisis tersebut maka dipilih inovasi pembelajaran outdoor learning yang memanfaatkan lingkungan sebagai sumber dan media belajar bagi siswa untuk mengembangkan kreativitas siswa.

\section{c. Analisis Konsep}

Analisis konsep bertujuan untuk mengidentifikasi dan menyusun materi pembelajaran menggambar yang relevan yang diajarkan berdasarkan analisis ujung depan. Materi pembelajaran yang dibuat adalah materi kelas IV semester 1 . Materi menggambar tersebar dalam beberapa tema dan sub tema yaitu: (1) tema Peduli Terhadap Makhluk Hidup, sub tema Hewan dan Tumbuhan di Lingkungan Sekolah, pembelajaran ke-6, (2) tema Berbagai Pekerjaan, sub tema Jenis-Jenis Pekerjaan, pembelajaran ke4, dan (3) tema Berbagai Pekerjaan, sub tema Barang dan Jasa, pembelajaran ke-5.

Materi menggambar terintegrasi dengan materi pembelajaran lain. Pada RPP 1 terdiri dari pelajaran SBdP dan Bahasa Indonesia dengan materi tentang tumbuhan. RPP 2 terdiri dari pelajaran IPS, bahasa Indonesia, SBdP dan IPA dengan materi sumber daya alam. RPP 3 terdiri dari pelajaran $\mathrm{PKn}$, bahasa Indonesia, SBdP dan IPA dengan materi tentang air.

d. Analisis Tugas

Analisis tugas merupakan pengidentifikasian tugas yang diperlukan dalam pembelajaran yang sesuai dengan kompetensi inti dan kompetensi dasar kurikulum 2013. Tugastugas yang diberikan kepada siswa yaitu: (1) mempresentasikan tugas-tugas seperti menjawab pertanyaan berdasarkan teks bacaan atau hasil diskusi berdasarkan pengamatan yang telah dikerjakan secara individu maupun kelompok di depan kelas, dan (2) menggambar sesuai dengan tema dan sub tema yang telah ditentukan secara kreatif.

\section{e. Merumuskan Tujuan Pembelajaran}

Rumusan tujuan pembelajaran mengacu pada kompetensi inti (KI), kompetensi dasar (KD) dan indikator pencapaian kompetensi yang telah disusun. RPP Pertemuan 1 adalah (1) Dengan mengamati, siswa mampu menggambar tumbuhan di sekitar lingkungan rumah secara kreatif, (2) Dengan mengamati, mempresentasikan hasil gambar tentang bagianbagian tumbuhan dan fungsinya dengan teliti. Rencana Pelaksanaan Pembelajaran Pertemuan 2 adalah (1) Dengan mengamati gambar, siswa mampu menjelaskan hubungan berbagai sumber daya alam dengan jenis-jenis pekerjaan dengan teliti, (2) Dengan mengamati gambar-gambar pekerjaan, siswa mampu membedakan pekerjaan yang menghasilkan benda dan pekerjaan yang menghasilkan jasa dengan teliti, (3) Dengan membaca teks sumber daya alam, siswa mampu

$$
\text { Copyright } \odot 2018 \text {, JRPD, ISSN } 2615 \text { - } 1723 \text { (Print), ISSN } 2615 \text { - } 1766 \text { (Online) }
$$


membedakan sumber daya alam yang dapat diperbarui dan sumber daya alam yang tidak dapat diperbarui dengan teliti, (4) Dengan mengamati alam, siswa mampu menggambar alam berdasarkan instruksi yang diberikan guru dengan kreatif, (5) Dengan membaca teks sumber daya alam, siswa mampu menemukan informasi tentang sumber daya alam (bambu, kayu, dan logam) dengan teliti, dan (6) Setelah membaca teks sumber daya alam, siswa mampu menjelaskan hubungan sumber daya alam dengan kondisi lingkungan tempat hidup masyarakat dengan bahasa yang santun. Rencana Pelaksanaan Pembelajaran Pertemuan 3 adalah (1) Dengan berdiskusi, siswa mampu membuat refleksi sikap tentang penggunaan air dalam kehidupan sehari-hari dengan teliti, (2) Dengan kegiatan membaca, siswa mampu menggali informasi teks laporan tentang hasil pemanfaatan sumber daya air dengan rasa ingin tahu, (3) Dengan mengamati lingkungan, siswa berkreasi membuat gambar yang berkaitan dengan air.

\section{Tahap Perancangan}

Tahap perancangan bertujuan untuk merancang perangkat pembelajaran. Langkahlangkah dalam tahap ini sebagai berikut:

a. Pemilihan Media

Pemilihan media dilakukan untuk mengidentifikasi media pembelajaran yang relevan dengan karakteristik materi. Media pembelajaran yang dipilih disesuaikan dengan analisis konsep, analisis tugas dan karakteristik siswa. Media yang dipilih pada penelitian ini adalah (1) tumbuhan yang ada di sekitar sekolah, (2) gambar hasil karya siswa, (3) video teknik mewarnai gambar menggunakan krayon, (4) meja, kursi, lemari dan pintu, (5) pemandangan ladang/kebun di sekitar sekolah, dan (6) kegiatan mencuci tangan dan menyiram bunga di sekolah. Alat yang digunakan dalam mewarnai gambar adalah krayon, karena memiliki variasi warna lebih banyak dibandingkan dengan pensil warna.
Penggunaan krayon bertujuan menambah pengetahuan, pengalaman dan keterampilan siswa selain pensil warna dalam mewarnai gambar.

b. Perancangan Awal

Rancangan awal perangkat pembelajaran meliputi RPP, materi pembelajaran dan pengukuran kreativitas. Pelaksanaan rancangan awal dapat dijelaskan sebagai berikut:

1) Rencana Pelaksanaan Pembelajaran

Rencana Pelaksanaan Pembelajaran (RPP) disusun setelah dilaksanakan pemetaan kompetensi dasar dan indikator pencapaian kompetensi sesuai dengan tema dan sub tema yang telah ditentukan. Pemetaan diperlukan untuk memudahkan dalam menyusun RPP. Komponen RPP terdiri atas identitas sekolah yaitu nama satuan pendidikan, identitas mata pelajaran atau tema/sub tema, kelas/semester, materi pokok, alokasi waktu, tujuan pembelajaran kompetensi dasar dan indikator pencapaian kompetensi, materi pembelajaran, metode pembelajaran, media pembelajaran, sumber belajar, langkah-langkah pembelajaran, dan penilaian hasil pembelajaran.

2) Materi Pembelajaran

Materi pembelajaran disusun dan dikembangkan sesuai dengan rencana pelaksanaan pembelajaran yang telah disusun. Materi pada RPP pertemuan pertama yaitu tumbuhan di lingkungan rumah. Materi pada RPP pertemuan kedua mengenai jenis-jenis pekerjaan. Materi RPP pertemuan ketiga berisi tentang barang dan jasa.

\section{3) Pengukuran Kreativitas}

Kreativitas terdiri atas 4 subkemampuan yaitu kelancaran, keaslian, keluwesan dan kerincian. Kelancaran adalah banyaknya ide atau gagasan yang muncul. Keluwesan adalah kemampuan melihat suatu masalah dari berbagai arah. Keaslian adalah ide atau gagasan yang dimiliki berbeda dengan ide kebanyakan orang. Kerincian adalah kemampuan mengembangkan ide sampai selesai dan mendetail. 


\section{Tahap Pengembangan}

Tahap pengembangan adalah tahap untuk menghasilkan perangkat pembelajaran menggambar berbasis outdoor learning yang valid dan efektif untuk mengembangkan kreativitas siswa. Tahap ini terdiri atas 3 tahap yaitu validasi ahli, uji coba terbatas dan uji coba sesungguhnya. Uraian dari ketiga tahap tersebut sebagai berikut:

a. Validasi Ahli

Perangkat pembelajaran yang telah dirancang selanjutnya divalidasi oleh para ahli. Validasi dari para ahli bertujuan untuk memperoleh perangkat pembelajaran valid dari aspek format, bahasa dan isi. Hasil validasi ahli digunakan sebagai uji kelayakan dan masukan untuk memperbaiki perangkat pembelajaran yang telah dikembangkan.

Secara garis besar masukan dan perbaikan dari validator dapat dilihat pada Tabel 9.

Tabel 9. Masukan dan Perbaikan Validator

\begin{tabular}{crl}
\hline RPP & & Masukan dan Perbaikan Validator \\
\hline RPP & 1) & Setiap ada kata seni sebaiknya \\
1. & & dirangkaikan kata menggambar sebab \\
& jenis seni banyak ragamnya, misalnya \\
& : tari, musik, dan drama \\
& 2) & Sebaiknya setiap \\
& dicantumkan nomornya \\
& 3) & Pada langkah-langkah pembelajaran \\
& perlu kegiatan absensi, mengajak \\
& siswa menyiapkan fisik dan psikis \\
& dengan bernyanyi "Kebunku", \\
& ciptakan situasi pembelajaran yang \\
& PAKEM. \\
4) & Perlu adanya penambahan gambar \\
& pada materi agar menjadi lebih jelas \\
& dan menarik. \\
\hline RPP & 1) & Penulisan/tata tulis harap dicermati \\
2. & menyesuaikan EYD \\
2) & Penomoran pada setiap halaman \\
& diperlukan demi sistematika \\
3) & Sub tema/pokok bahasan dalam \\
& identitas mata pelajaran \\
4) & Metode perlu ditambah agar \\
\hline &
\end{tabular}

\begin{tabular}{|c|c|c|}
\hline $\mathrm{RPP}$ & & Masukan dan Perbaikan Validator \\
\hline & & $\begin{array}{l}\text { pembelajaran lebih bermakna bagi } \\
\text { siswa }\end{array}$ \\
\hline & 5) & Munculkan situasi pembelajaran \\
\hline & & PAKEM dalam langkah pembelajaran \\
\hline & 6) & $\begin{array}{lr}\text { Rencanakan } & \text { program } \\
\text { perbaikan/pengayaan } & \text { munculkan } \\
\text { dalam langkah kegiatan. } & \end{array}$ \\
\hline & 7) & $\begin{array}{l}\text { Perhatikan penggunaan kata baku dan } \\
\text { tidak baku dalam penulisan RPP dan } \\
\text { materi pembelajaran. }\end{array}$ \\
\hline $\mathrm{RPF}$ & 1) & Pada identitas mata pelajaran sub \\
\hline 3. & & $\begin{array}{l}\text { tema diberi garis miring kemudian } \\
\text { tulis pokok bahasan }\end{array}$ \\
\hline & 2) & Tata warna dalam media/alat \\
\hline & & $\begin{array}{l}\text { pembelajaran harus dipastikan dalam } \\
\text { kondisi terang warna, hindarkan } \\
\text { warna buram (samar-samar) }\end{array}$ \\
\hline & 3) & $\begin{array}{l}\text { Perlu penambahan indikator agar } \\
\text { aspek penilaian tercapai }\end{array}$ \\
\hline & 4) & $\begin{array}{l}\text { Perlu penambahan metode } \\
\text { pembelajaran agar lebih bervariasi }\end{array}$ \\
\hline & 5) & $\begin{array}{l}\text { Pada kegiatan awal perlu kegiatan } \\
\text { absensi }\end{array}$ \\
\hline & 6) & $\begin{array}{lr}\text { Sebelum } & \text { kegiatan } \\
\text { penjelasan/penyampaian } & \text { tujuan }\end{array}$ \\
\hline & & $\begin{array}{l}\text { mengajak siswa untuk persiapan fisik } \\
\text { dan psikis seperti bernyanyi }\end{array}$ \\
\hline & 7) & $\begin{array}{l}\text { Penilaian K } 13 \text { sudah baik, bila soal } \\
\text { uraian perlu rentang nilai }\end{array}$ \\
\hline & 8) & $\begin{array}{l}\text { Perhatikan penggunaan kata di awal } \\
\text { paragraf. }\end{array}$ \\
\hline
\end{tabular}

b. Uji Coba Terbatas

Uji coba terbatas dilaksanakan pada siswa

kelas V SDN 1 Tambak sebanyak 9 siswa. Pelaksana uji coba terbatas adalah guru kelas $\mathrm{V}$ SDN 1 Tambak sebagai guru model. Guru model dipilih untuk mengetahui respons guru terhadap perangkat pembelajaran menggambar dan kendala yang dialami pada pelaksanaan pembelajaran menggambar uji coba terbatas.

Hasil yang diperoleh pada uji coba terbatas yang meliputi aktivitas siswa, respons siswa, respons guru dan kreativitas. 
Aktivitas siswa pada pembelajaran uji coba terbatas diperoleh rata-rata sebesar 22,14, termasuk dalam kategori aktif dengan jumlah siswa 9 anak. Respons siswa terhadap pembelajaran menggambar berbasis outdoor learning diperoleh rata-rata sebesar 29,2 yang termasuk dalam kategori sangat positif. Respons guru terhadap pembelajaran menggambar berbasis outdoor learning dalam kategori sangat positif, dari rata-rata respons sebesar $80 \%$. Perangkat pembelajaran menggambar berbasis outdoor learning dapat dijadikan mudah diterapkan dalam pembelajaran, dapat mengembangkan kreativitas dan aktivitas siswa, memudahkan siswa menemukan ide/gagasan dalam menggambar serta siswa menjadi senang, semangat, antusias mengikuti proses pembelajaran. Kreativitas siswa sebelum pelaksanaan pembelajaran outdoor learning diperoleh rata-rata 5 , setelah dilaksanakan pembelajaran outdoor learning diperoleh rata-rata 6,56 .

Hasil uji sign kreativitas siswa diperoleh hasil, 1 siswa mengalami penurunan skor, sedangkan 8 siswa mengalami peningkatan skor kreativitas siswa. Kolom exact sig (2-tailed) diperoleh angka sebesar 0,012, dengan taraf kesalahan sebesar 5\% $(0,05)$ maka harga 0,012 lebih kecil dari 0,05. Maka dapat disimpulkan bahwa terdapat pengaruh yang positif dan signifikan pembelajaran outdoor learning terhadap pengembangan kreativitas siswa.

c. Uji coba sesungguhnya

Uji coba sesungguhnya dilakukan untuk mengukur kreativitas siswa, aktivitas siswa, respons siswa terhadap pelaksanaan pembelajaran outdoor learning dan respons guru terhadap perangkat pembelajaran menggambar outdoor learning yang telah disusun. Uji coba sesungguhnya dilaksanakan pada siswa kelas IV SDN 1 Tambak tahun ajaran 2015/2016 sebagai kelas kontrol dan siswa kelas IV SDN 2 Singosari tahun ajaran 2015/2016 sebagai kelas eksperimen. Kelas kontrol sejumlah 19 siswa dan kelas eksperimen sejumlah 21 siswa. Pelaksanaan pembelajaran menggambar pada kelas kontrol dilaksanakan di dalam kelas dengan memanfaatkan media gambar dan video sebagai pembanding kelas eksperimen.

Pelaksana uji coba sesungguhnya pada kelas eksperimen adalah guru kelas IV SDN 2 Singosari sebagai guru model. Guru model dipilih untuk mengetahui respons guru terhadap perangkat pembelajaran menggambar dan pelaksanaan pembelajaran menggambar uji coba sesungguhnya. Persiapan yang dilakukan kepada guru model sebelum pelaksanaan uji coba sesungguhnya yaitu: (1) menyiapkan perangkat pembelajaran menggambar, media, alat dan sumber belajar, (2) penjelasan tentang menggambar, outdoor learning dan kreativitas, (3) pengarahan langkah-langkah pembelajaran dan kendala pelaksanaan kegiatan pembelajaran menggambar yang ditemukan pada uji coba terbatas. Kegiatan pembelajaran menggambar berbasis outdoor learning uji coba sesungguhnya dilaksanakan 3 kali pertemuan.

\section{PEMBAHASAN}

Pembahasan hasil penelitian meliputi: (1) perangkat pembelajaran faktual, (2) karakteristik perangkat pembelajaran menggambar berbasis outdoor learning untuk siswa kelas IV kurikulum 2013, (3) kevalidan perangkat pembelajaran menggambar berbasis outdoor learning yang telah dikembangkan, (4) efektifitas perangkat pembelajaran menggambar berbasis outdoor learning dalam mengembangkan kreativitas siswa, dan (5) produk perangkat pembelajaran menggambar berbasis outdoor learning dalam mengembangkan kreativitas siswa.

\section{a. Perangkat Pembelajaran Faktual}

Rencana Pelaksanaan Pembelajaran (RPP) adalah rencana yang menggambarkan prosedur dan pengorganisasian pembelajaran untuk mencapai satu kompetensi dasar yang telah ditetapkan dalam Standar Isi. RPP berfungsi

$$
\text { Copyright }(2018 \text {, JRPD, ISSN } 2615 \text { - } 1723 \text { (Print), ISSN } 2615 \text { - } 1766 \text { (Online) }
$$




\section{Jurnal Riset Pendidikan Dasar, 01 (2), Oktober 2018 (84-100)}

Atik Nur Wahyuningsih, Kustiarini

sebagai rambu-rambu bagi guru dalam mengajar yang berupa tujuan akhir yang akan dicapai setelah pembelajaran, materi pembelajaran yang akan disampaikan, metode dan pendekatan yang akan digunakan, langkah-langkah pembelajaran yang akan dilaksanakan, alat, media dan sumber belajar yang akan digunakan, dan jenis, bentuk serta instrumen penilaian yang akan digunakan (Komalasari, 2013:193-194).

Beberapa kriteria perangkat pembelajaran yang baik adalah (1) RPP memenuhi komponen dan struktur minimal yaitu tujuan pembelajaran, materi pembelajaran, metode pembelajaran, langkah-langkah pembelajaran, sumber pembelajaran dan penilaian hasil belajar, (2) komponen-komponen RPP saling berhubungan secara fungsional dan menunjang pencapaian indikator kompetensi dasar, (3) RPP menyajikan cakupan, kedalaman, tingkat kesukaran, dan urutan materi yang sesuai dengan tingkat perkembangan siswa SD dan memperhatikan perkembangan ilmu, teknologi dan seni mutakhir dalam kehidupan nyata, dan peristiwa yang terjadi, (4) RPP menyajikan metode dan langkahlangkah pembelajaran yang aktif, kreatif, efektif dan menyenangkan, (5) RPP menyajikan penilaian hasil belajar dengan aspek dan teknik penilaian yang beragam, (6) RPP menyajikan sumber belajar beragam, mudah diperoleh, tersedia di lingkungan sekitar siswa dan sekolah, murah, dan efektif hasilnya, dan (7) keseluruhan komponen RPP dapat digunakan oleh guru atau disesuaikan dengan dinamika perubahan yang terjadi di sekolah dan tuntutan masyarakat (Komalasari, 2013:197).

Perangkat pembelajaran yang disusun oleh guru kelas IV SDN 2 Singosari sudah cukup baik namun masih terdapat beberapa kekurangan, diantaranya (1) $\mathrm{KD}$ ranah spiritual dan sikap belum dicantumkan, (2) kurangnya kesesuaian antara beberapa komponen RPP seperti materi pembelajaran, media, alat dan sumber belajar, langkah-langkah pembelajaran dan penilaian. Perangkat pembelajaran yang telah ada perlu direvisi dan dikembangkan dengan pendekatan pembelajaran yang dapat menciptakan proses pembelajaran yang aktif, kreatif, efektif dan menyenangkan. Salah satu pendekatan pembelajaran yang dapat digunakan untuk mengembangkan perangkat pembelajaran adalah outdoor learning dalam upaya pengembangan kreativitas siswa.

\section{b. Karakteristik Perangkat Pembelajaran Menggambar Berbasis Outdoor Learning}

Perangkat pembelajaran menggambar berbasis outdoor learning diadopsi dari sintaks pembelajaran tematik terpadu dan elemen penting pendekatan outdoor learning. Sintaks pembelajaran menggambar berbasis outdoor learning meliputi (1) tahap pendahuluan, (2) tahap eksplorasi, (3) tahap outdoor learning berbasis lingkungan sekolah, (4) tahap elaborasi, dan (5) tahap presentasi. Elemen penting dalam pembelajaran outdoor learning adalah alam terbuka sebagai sarana kelas, berkunjung ke objek langsung, unsur bermain sebagai dasar pendekatan dan guru harus mempunyai komitmen (Yuliarto, 2010:14). Perangkat pembelajaran yang telah dikembangkan dapat digunakan sebagai pedoman guru dalam melaksanakan pembelajaran berbasis outdoor learning.

Langkah-langkah kegiatan pembelajaran dan materi pembelajaran menggambar berbasis outdoor learning yang dikembangkan berkaitan dengan situasi nyata (Montgomery dan Millenbah, 2011:45). Siswa melakukan interaksi dengan objek dan lingkungan secara langsung sehingga pembelajaran dapat bermakna bagi kehidupan siswa. Selain itu, outdoor learning memiliki kelebihan sebagai berikut: (1) siswa lebih banyak melakukan kegiatan-kegiatan yang secara tidak langsung melibatkan kerjasama antarteman, (2) memunculkan proses komunikasi, pemecahan masalah, kreativitas, pengambilan keputusan, saling memahami dan menghargai perbedaan dan (3) lebih fleksibel, mengutamakan kreativitas dan inisiatif berdasarkan daya nalar siswa (Husamah, 2013:21 \& 24), (4) pengajaran di luar kelas dapat 
meningkatkan motivasi, komunikasi dan partisipasi diantara siswa, (5) siswa dapat berbagi pengalaman yang diperoleh di lingkungan sekitar dan dapat menjadi titik permulaan program pembelajaran di dalam kelas, (6) pengajaran di luar kelas dapat mengembangkan dan memperkuat pembelajaran yang telah diperoleh siswa di dalam kelas (Fagerstam, 2014:56), serta (7) outdoor learning dapat memberikan pengalaman langsung yang memberikan kesan mendalam pada siswa (Utomo, 2015:6).

Berdasarkan karakteristik perangkat pembelajaran di atas, dapat dikatakan bahwa perangkat pembelajaran yang dikembangkan sesuai dengan karakteristik pembelajaran kurikulum 2013 yaitu pendekatan saintifik dalam pengembangan ranah keterampilan yaitu kreativitas. Perangkat pembelajaran dengan outdoor learning dan kontekstual dapat membantu siswa lebih mudah memahami materi pembelajaran dan menghubungkan pengetahuan yang dimilikinya dengan situasi nyata sehingga pembelajaran dapat lebih bermakna bagi siswa.

\section{c. Kevalidan Perangkat Pembelajaran Menggambar Berbasis Outdoor Learning}

Produk perangkat pembelajaran menggambar berbasis outdoor learning yang dikembangkan terdiri atas RPP, materi pembelajaran dan pengukuran kreativitas. Perangkat pembelajaran dikembangkan menggunakan modifikasi model 3D Thiagarajan yang terdiri atas tahap pendefinisian, tahap perancangan dan tahap pengembangan. Tahap pendefinisian terdiri atas analisis ujung depan, analisis siswa, analisis konsep, analisis tugas dan merumuskan tujuan pembelajaran. Tahap perancangan terdiri atas tahap pemilihan media dan perancangan awal. Tahap pengembangan terdiri atas validasi ahli perangkat pembelajaran, uji coba terbatas dan uji coba sesungguhnya. Murdiyani (2012:47) pada penelitiannya dalam mengembangkan perangkat pembelajaran model e-learning Biologi menggunakan modifikasi model 3D Thiagarajan. Pengembangan perangkat pembelajaran menggunakan modifikasi model 3D Thiagarajan karena tahap-tahap pengembangannya lebih rinci dan sistematis.

Produk perangkat pembelajaran menggambar berbasis outdoor learning divalidasi oleh ahli perangkat pembelajaran dan praktisi pendidikan untuk menilai kelayakan perangkat pembelajaran sebelum diujicobakan secara terbatas.. Aspek yang dinilai adalah isi komponen perangkat pembelajaran dan tata bahasa. Hasil validasi oleh ahli perangkat pembelajaran yaitu dosen Fakultas Ilmu Pendidikan di Universitas Negeri Semarang dan dosen Fakultas Ilmu Tarbiyah dan Keguruan di IAIN Surakarta memberikan penilaian sangat baik. Hasil validasi praktisi pendidikan yaitu Kepala SD Negeri Sumbung 1 memberikan penilaian sangat baik. Data hasil validasi ketiga ahli dengan kriteria sangat baik menunjukkan bahwa perangkat pembelajaran layak untuk diujicobakan pada skala terbatas.

\section{d. Efektifitas Perangkat Pembelajaran Menggambar Berbasis Outdoor Learning}

Keefektifan perangkat pembelajaran menggambar berbasis outdoor learning hasil uji coba sesungguhnya dilihat dari empat aspek yaitu aktivitas siswa, respons siswa, respons guru dan kreativitas siswa. Aktivitas siswa yang diobservasi meliputi aktivitas fisik, psikis dan sosial. Aktivitas fisik antara lain kegiatan melihat, kegiatan lisan, kegiatan mendengarkan, kegiatan menulis, kegiatan menggambar, kegiatan gerak. Aktivitas psikis berupa kegiatan mental dan kegiatan emosional. Aktivitas sosial berupa diskusi pada kegiatan lisan. Beragam aktivitas siswa muncul dalam pembelajaran karena situasi pembelajaran menggambar berbasis outdoor learning yang memberikan peluang bagi siswa melalukan berbagai aktivitas pada siswa yang dapat memberikan kontribusi positif terhadap hasil belajar siswa (Rachmawati, 2013:77).

Kreativitas diukur berdasarkan empat sub kemampuan yaitu kelancaran, keluwesan,

$$
\text { Copyright } \odot 2018 \text {, JRPD, ISSN } 2615 \text { - } 1723 \text { (Print), ISSN } 2615 \text { - } 1766 \text { (Online) }
$$


keaslian, dan kerincian (Tabrani, 2014:25). Kelancaran terdiri atas tiga indikator yaitu gambar diwarnai dengan banyak variasi, objek gambar dibuat secara beragam dan gambar diselesaikan dengan tuntas. Keluwesan terdiri atas dua indikator yaitu gambar diwarnai dengan rapi dan bersih dan menunjukkan modifikasi gambar. Keaslian terdiri atasdua indikator yaitu bentuk atau objek gambar yang dibuat berbeda dari objek yang ada dan gambar yang dibuat dengan cara yang orisinil. Kerincian terdiri atas tiga indikator yaitu gambar dibuat sesuai tema, membentuk komposisi yang serasi dan menunjukkan kesesuaian objek dengan objek lainnya. Secara keseluruhan terdapat sepuluh indikator kreativitas.

Uji homogenitas dilakukan untuk mengetahui subjek uji coba memiliki kesamaan varians skor atau tidak pada sampel kelas eksperimen dan kelas kontrol sebelum mengolah data kreativitas secara statistik. Hasil uji homogenitas data pretest diperoleh nilai signifikansi sebesar 0,833 dan data posttest diperoleh nilai signifikansi sebesar 0,746 yang memiliki nilai lebih besar dari 0,05 yang menunjukkan bahwa kelas eksperimen dan kontrol memiliki varians yang sama atau homogen. Hal ini menunjukkan bahwa kreativitas hasil menggambar siswa tidak terdapat perbedaan sebelum diterapkan pendekatan outdoor learning.

Kreativitas dianalisis secara statistik menggunakan rumus Uji Tanda. Hasil Uji Tanda kreativitas siswa pada kelas eksperimen, siswa yang skor kreativitas meningkat sebesar $90,47 \%$, siswa yang skor kreativitas tidak berubah sebesar $0 \%$, siswa yang skor kreativitas menurun sebesar $4,76 \%$ dan taraf signifikansi diperoleh skor 0,00 lebih kecil dari 0,05. Hasil Uji Tanda pada kelas kontrol, siswa yang skor kreativitas meningkat sebesar $78,95 \%$, siswa yang skor kreativitas tidak berubah sebesar $5 \%$, siswa yang skor kreativitas menurun sebesar $21,05 \%$ dan taraf signifikansi diperoleh skor 0,019 lebih kecil dari 0,05. Hasil
Uji Tanda pada kelas eksperimen dan kelas kontrol.

Kegiatan pembelajaran pada kelas eksperimen, siswa diberikan kebebasan mengeksplorasi dan mengamati objek menggambar di luar kelas. Outdoor learning dapat memberikan pengalaman langsung yang memberikan kesan mendalam pada siswa (Utomo, 2015:6), Kreativitas dikembangkan salah satunya melalui pembelajaran menggambar karena diyakini adanya keterkaitan antara kemampuan menggambar dengan kreativitas. Kegiatan menggambar menawarkan banyak aspek pendukung dalam pemikiran kreativitas siswa (Chan and Chan, 2007:77). Kreativitas merupakan faktor penting dalam berpikir dan belajar dalam berbagai disiplin ilmu (Mastuti dkk, 2016:33), berperan penting dalam menghasilkan pengetahuan, inovasi, tuntutan masyarakat (Alencar \& Oliveira, 2016:555), relevan dengan kompetensi yang diperlukan pada abad ke-21 (Trnova, 2014:8), diperlukan untuk memecahkan masalah yang bersifat divergen dan perkembangan kemandirian siswa (Utomo \& Ardiyarta, 2013:3).

Respons siswa terhadap pelaksanaan pembelajaran menggambar berbasis outdoor learning diperoleh rata-rata sebesar 83,05\% dalam kategori sangat positif. Sebagian besar siswa menganggap outdoor learning lebih menyenangkan, tidak membosankan, lebih termotivasi dan lebih memudahkan dalam menemukan ide atau gagasan dalam menggambar. Respons guru terhadap perangkat pembelajaran menggambar berbasis outdoor learning sebesar $85 \%$. Perangkat pembelajaran menggambar berbasis outdoor learning ini dapat dijadikan pedoman bagi guru dalam mengembangkan perangkat pembelajaran pada materi pembelajaran yang lain dengan memanfaatkan media dan sumber belajar dari lingkungan.

$$
\text { Copyright } \odot 2018 \text {, JRPD, ISSN } 2615 \text { - } 1723 \text { (Print), ISSN } 2615 \text { - } 1766 \text { (Online) }
$$




\section{Jurnal Riset Pendidikan Dasar, 01 (2), Oktober 2018 (84-100)}

Atik Nur Wahyuningsih, Kustiarini

\section{e. Produk Perangkat Pembelajaran \\ Menggambar Berbasis Outdoor Learning}

Produk perangkat pembelajaran menggambar berbasis outdoor learning berupa buku pedoman yang disusun dalam bentuk buku dengan ukuran kertas A4, tebal buku 72 halaman. Buku yang disusun terdiri atas tiga bagian yaitu halaman depan, isi dan halaman belakang. Halaman depan terdiri atas judul buku, prakata, kata pengantar, dan daftar isi. Bagian isi terdiri atas 13 bab yaitu (1) petunjuk penggunaan RPP, (2) peralatan menggambar, (3) outdoor learning, (4) kreativitas, (5) pemetaan indikator 1, (6) RPP 1, (7) tumbuhan di lingkungan sekolah, (8) pemetaan indikator 2, (9) RPP 2, (10) jenisjenis pekerjaan, (11) pemetaan indikator 3 , (12) RPP 3, (13) barang dan jasa. Halaman belakang terdiri atas daftar pustaka, biodata penulis dan gambaran tentang isi buku. Buku pedoman perangkat pembelajaran menggambar merupakan acuan pendidik dalam mengembangkan perangkat pembelajaran menggunakan outdoor learning (Retnowati, 2009:164). Buku pedoman perangkat pembelajaran menggambar berbasis Outdoor Learning terdapat penjelasan/keterangan tentang RPP, peralatan menggambar, outdoor learning dan kreativitas untuk memberikan dukungan yang memadai bagi guru dalam mengembangkan dan melaksanakan outdoor learning (Derwing, Diepenbroek \& Foote, 2012:36-37).

\section{SIMPULAN}

Simpulan penelitian adalah perangkat pembelajaran menggambar berbasis outdoor learning yang dikembangkan memenuhi kriteria valid dan efektif untuk mengembangkan kreativitas siswa. Guru dapat menggunakan buku pedoman perangkat pembelajaran menggambar berbasis outdoor learning karena terbukti dapat mengembangkan kreativitas siswa. Siswa dapat menggunakan outdoor learning untuk meningkatkan kreativitas.
Berdasarkan hasil pengembangan perangkat pembelajaran menggambar berbasis outdoor learning, maka diharapkan guru atau peneliti selanjutnya dapat melakukan penelitian dan pengembangan tentang perangkat pembelajaran memuat semua mata pelajaran dalam tema dan sub tema yang sudah ada sehingga dapat menjadi karya yang lebih sempurna, selain itu penelitian juga perlu dilakukan di sekolah lain agar dapat diperoleh temuan-temuan yang lebih bervariasi dan sampel penelitian dapat lebih representatif.

\section{DAFTAR PUSTAKA}

Arikunto, S. 2010. Prosedur Penelitian Suatu Pendekatan Praktik. Jakarta: Rineka Cipta.

Bruner. 1977. The Process of Education. Cambridge: Harvard University Press.

Chan, D. W., \& Chan, L. K. 2007. Creativity and Drawing Abilities of Chinese Students in Hong Kong: Is There a Connection?. New Horizons in Education. 55 (3): 77-94

Fagerstam, E., \& Samuelsson, J. 2012. Learning Arithmetic Outdoors in Junior High School - Influence on Performance and Self-Regulating Skills.

Hamalik, O. 2004. Proses Belajar Mengajar. Jakarta: Bumi Aksara.

Husamah. 2013. Pembelajaran Luar Kelas Outdoor Learning. Jakarta: Prestasi Pustakarya.

Kemendikbud. 2013. Permendikbud Nomor $81 \mathrm{~A}$ tentang Implementasi Kurikulum. Jakarta: Kementerian Pendidikan dan Kebudayaan.

Komalasari, K. 2013. Pembelajaran Kontekstual Konsep dan Aplikasi. Bandung: Refika Aditama.

Mardapi, D. 2012. Pengukuran, Penilaian dan Evaluasi Pendidikan. Yogyakarta: Nuha Medika.

Munandar, U. 2012. Pengembangan Kreatifitas Anak Berbakat. Jakarta: Rineka Cipta.

Rachmawati, N. 2013. Pengembangan Copyright @2018, JRPD, ISSN 2615 - 1723 (Print), ISSN 2615 - 1766 (Online) 
Perangkat Pembelajaran IPS Terpadu Berbasis Outdoor Learning. Journal of Primary Educational. 2 (2): 77-83.

Retnowati, T. H. 2009. Pengembangan Instrumen Penilaian Seni Lukis Anak di Sekolah Dasar. Disertasi. Yogyakarta: Program Pascasarjana Universitas Negeri Yogyakarta.

Sadiman, A. S. 1990. Media Pendidikan Pengertian, Pengembangan, dan Pemanfaatannya. Jakarta: Rajawali.

Sugiyono. 2013. Metode Penelitian Pendidikan Pendekatan Kuantitif, Kualitatif, dan $R \& D$. Bandung: Alfabeta.

Tabrani, P. 2014. Proses Kreasi Gambar Anak Proses Belajar. Jakarta: Erlangga.

Thiagarajan, S., Semmel, D. S., \& Semmel, M. I. 1974. Instructional Development for Training Teachers of Exceptional Children: A Sourcebook. Minnesota: Leadership Training Institute/Special Education, University of Minnesota.

Trnova, E. 2014. IBSE and Creativity Development. Science Education International. 25 (1): 8-18.

Zwick, T. T., \& Miller, K. W. 1996. A Comparison of Integrated Outdoor Education Activities and Traditional Science Learning with American Indian Students. Journal of American Indian Education. 35 (2): 1-9. 